\title{
Impacts of the production and consumption of biofuels on stratospheric ozone
}

\author{
Laura E. Revell, ${ }^{1,2}$ Greg E. Bodeker, ${ }^{3}$ Petra E. Huck, ${ }^{3}$ and Bryce E. Williamson ${ }^{2}$ \\ Received 28 February 2012; revised 10 April 2012; accepted 17 April 2012; published 18 May 2012.
}

[1] Biofuels are becoming increasingly popular sources of renewable energy as economic pressures and environmental consequences encourage the use of alternatives to fossil fuels. However, growing crops destined for use as biofuels incurs large $\mathrm{N}_{2} \mathrm{O}$ emissions associated with the use of nitrogen-based fertilizers. Besides being a greenhouse gas, $\mathrm{N}_{2} \mathrm{O}$ is also the primary source of stratospheric $\mathrm{NO}_{\mathrm{x}}$ $\left(\mathrm{NO}+\mathrm{NO}_{2}\right)$ which leads to stratospheric ozone depletion. In this paper, the potential effects on the ozone layer of a largescale shift away from fossil fuel use to biofuels consumption over the 21 st century are examined. Under such a scenario, global-mean column ozone decreases by 2.6 DU between 2010 and 2100 in contrast to a 0.7 DU decrease under a control simulation (the IPCC SRES B1 scenario for greenhouse gases) and a 9.1 DU increase under the more commonly used SRES A1B scenario. Two factors cause the decrease in ozone in the biofuels simulation: 1) large $\mathrm{N}_{2} \mathrm{O}$ emissions lead to faster rates of the ozone-depleting $\mathrm{NO}_{\mathrm{x}}$ cycles and; 2) reduced $\mathrm{CO}_{2}$ emissions (due to less fossil fuel burning) lead to relatively less stratospheric cooling over the 21 st century, which decreases ozone abundances. Reducing $\mathrm{CO}_{2}$ emissions while neglecting to reduce $\mathrm{N}_{2} \mathrm{O}$ emissions could therefore be damaging to the ozone layer. Citation: Revell, L. E., G. E. Bodeker, P. E. Huck, and B. E. Williamson (2012), Impacts of the production and consumption of biofuels on stratospheric ozone, Geophys. Res. Lett., 39, L10804, doi:10.1029/2012GL051546.

\section{Introduction}

[2] As fossil fuel reserves diminish and awareness of the detrimental effects of fossil fuel-burning on global climate continues to grow, biofuels are becoming an increasingly attractive supply of fuel, especially in Europe, the USA and Brazil [Bessou et al., 2011]. In 2010, biofuels accounted for $2.7 \%$ of road-transportation fuel use globally (http://vitalsigns. worldwatch.org/vs-trend/biofuels-regain-momentum). Biofuels are often considered to be carbon neutral because the $\mathrm{CO}_{2}$ released on burning had previously been removed from the atmosphere via photosynthesis. However, nitrogen-based fertilizers used in growing the crops from which biofuels are produced lead to $\mathrm{N}_{2} \mathrm{O}$ emissions via soil nitrification and

\footnotetext{
${ }^{1}$ National Institute of Water and Atmospheric Research, Christchurch, New Zealand.

${ }^{2}$ Department of Chemistry, University of Canterbury, Christchurch, New Zealand.

${ }^{3}$ Bodeker Scientific, Alexandra, New Zealand.

Corresponding author: L. E. Revell, National Institute of Water and Atmospheric Research, 10 Kyle St., Christchurch 8440, New Zealand. (laura.revell@niwa.co.nz)

Copyright 2012 by the American Geophysical Union. 0094-8276/12/2012GL051546
}

denitrification [Smeets et al., 2009]. $\mathrm{N}_{2} \mathrm{O}$ is a greenhouse gas (GHG) with a 100-year global warming potential of $\sim 298$, and a lifetime of $\sim 114$ years [Forster et al., 2007].

[3] Crutzen et al. [2008] suggested that the global warming reduction achieved through $\mathrm{CO}_{2}$ reductions by using first-generation biofuels (those produced from vegetable oil, starch or sugar) instead of fossil fuels, could be countered by the subsequent increase in $\mathrm{N}_{2} \mathrm{O}$ emissions resulting from increased nitrogen-based fertilizer use.

[4] Using linked economic and terrestrial biogeochemistry models, Melillo et al. [2009] found that carbon emissions resulting from land-use change under a global biofuels programme would be significant. However, they also found that an increase in $\mathrm{N}_{2} \mathrm{O}$ emissions due to increases in nitrogenbased fertilizer use would be a more important contributor to climate warming. Additionally, under two different scenarios in which biofuels production was projected to increase, they estimated this would account for $\sim 60 \%$ of total annual $\mathrm{N}_{2} \mathrm{O}$ emissions by 2100 .

[5] As well as being a GHG, $\mathrm{N}_{2} \mathrm{O}$ leads to stratospheric ozone destruction through its reaction with $\mathrm{O}\left({ }^{1} \mathrm{D}\right)$ to produce $\mathrm{NO}_{\mathrm{x}}\left(\mathrm{NO}+\mathrm{NO}_{2}\right)$ [Crutzen, 1970]. $\mathrm{NO}_{\mathrm{x}}$ depletes ozone by participating catalytically in the following cycles (ratedetermining steps in bold):

$$
\begin{array}{ll}
\text { [6] Cycle I: } & \text { Cycle II: } \\
\mathrm{NO}+\mathrm{O}_{3} \rightarrow \mathrm{NO}_{2}+\mathrm{O}_{2} & \mathrm{NO}+\mathrm{O}_{3} \rightarrow \mathrm{NO}_{2}+\mathrm{O}_{2} \\
\frac{\mathbf{N O}_{2}+\mathbf{O} \rightarrow \mathbf{N O}+\mathbf{O}_{2}}{\mathrm{O}_{3}+\mathrm{O} \rightarrow 2 \mathrm{O}_{2}} & \mathrm{NO}_{2}+\mathrm{O}_{3} \rightarrow \mathrm{NO}_{3}+\mathrm{O}_{2} \\
& \frac{\mathbf{N O}_{3}+\boldsymbol{h} \mathbf{v} \rightarrow \mathbf{N O}+\mathbf{O}_{2}}{2 \mathrm{O}_{3} \rightarrow 3 \mathrm{O}_{2}}
\end{array}
$$

[7] $\mathrm{N}_{2} \mathrm{O}$ is projected to be the dominant ozone-depleting gas emitted through the 21 st century [Ravishankara et al., 2009]. However, stratospheric cooling resulting from increases in other GHGs, primarily $\mathrm{CO}_{2}$, decreases the effectiveness of $\mathrm{N}_{2} \mathrm{O}$ as an ozone-depleting substance by: 1) increasing the sink for reservoir nitrogen species [Rosenfield and Douglass, 1998], and 2) decreasing the $\mathrm{O} / \mathrm{O}_{3}$ ratio [Jonsson et al., 2004], thus slowing the $\mathrm{NO}_{2}+\mathrm{O}$ ratedetermining step of Cycle I by decreasing the abundance of atomic oxygen. Furthermore, as sea-surface temperatures (SSTs) increase over the 21st century, the Brewer-Dobson circulation (BDC) is projected to strengthen [Fomichev et al., 2007], thus reducing the yield of $\mathrm{NO}_{\mathrm{x}}$ from $\mathrm{N}_{2} \mathrm{O}$ [Cook and Roscoe, 2009].

[8] Three chemistry-climate model (CCM) simulations 'A1B', 'B1' and 'biofuels' (Table 1) have been performed to examine the potential effects of increased production and consumption of biofuels on stratospheric ozone. The A1B and B1 simulations were based on the IPCC SRES A1B and $\mathrm{B} 1 \mathrm{GHG}$ emissions scenarios, respectively [Nakicenovic 
Table 1. Summary of the Three CCM Simulations

\begin{tabular}{lccc}
\hline & A1B & B1 & Biofuels \\
\hline $\mathrm{CO}_{2}$ in $2100(\mathrm{GtC})^{\mathrm{a}}$ & 13.1 & 5.2 & 3.7 \\
$\mathrm{~N}_{2} \mathrm{O}$ in $2100\left(\mathrm{MtN} \mathrm{O}_{2} \mathrm{O}-\mathrm{N}\right)^{\mathrm{a}}$ & 7.0 & 5.7 & 14.3 \\
$2090 \mathrm{~s}$ temperature $(\mathrm{K})^{\mathrm{b}}$ & 215.2 & 218.6 & 218.9 \\
$\Delta \mathrm{O}_{3}(\mathrm{DU})^{\mathrm{c}}$ & 9.1 & -0.7 & -2.6 \\
\hline
\end{tabular}

${ }^{\mathrm{a}} \mathrm{CO}_{2}$ and $\mathrm{N}_{2} \mathrm{O}$ emissions.

${ }^{\mathrm{b}}$ Global-mean temperatures at $30 \mathrm{hPa}$ simulated by NIWA-SOCOL, and averaged over the 2090 s decade.

${ }^{\mathrm{c}}$ Change in global-mean total column ozone over the 21 st century simulated by NIWA-SOCOL (2090s decade minus 2010s decade), expressed in Dobson Units.

and Swart, 2000]. The SRES A1B scenario portrays an intermediate increase in concentrations of anthropogenic GHGs, while SRES B1 prescribes relatively low GHG emissions. The A1B and $\mathrm{B} 1$ simulations display similar $\mathrm{N}_{2} \mathrm{O}$ surface concentrations but different $\mathrm{CO}_{2}$ surface concentrations and SSTs, which influence stratospheric temperatures and the BDC. This facilitated an investigation of how the $\mathrm{BDC}$ and $\mathrm{CO}_{2}$-induced stratospheric cooling influence ozone and ozone-depleting $\mathrm{NO}_{\mathrm{x}}$ chemistry. The major difference between the $\mathrm{B} 1$ and biofuels simulations was the $\mathrm{N}_{2} \mathrm{O}$ surface concentrations, permitting a study of the effect of increased $\mathrm{N}_{2} \mathrm{O}$ emissions on ozone as a result of increased nitrogenbased fertilizer use.

\section{Computational Methods}

[9] CCM simulations were performed using the NIWASOCOL (National Institute of Water and Atmospheric Research - SOlar Climate Ozone Links) model. NIWASOCOL is based on version 2.0 of the SOCOL model [Schraner et al., 2008; SPARC CCMVal, 2010], and includes 41 chemical species, 140 gas-phase reactions, 46 photolysis reactions and 16 heterogeneous reactions. The reaction rate constants used were those recommended by Sander et al. [2006, 2009]. NIWA-SOCOL performs chemical and radiative calculations every two hours, and dynamical process calculations every 15 minutes. The adjusted A1 scenario for halocarbon concentrations that accounts for the accelerated phase-out of HCFCs was used [Daniel et al., 2007], while the GHG concentrations prescribed for the three simulations are described in more detail below.

[10] NIWA-SOCOL tracks the contribution to ozone loss from 15 catalytic cycles, similar to the diagnostic approach used by Lee et al. [2002]. Odd oxygen $\left(\mathrm{O}+\mathrm{O}\left({ }^{1} \mathrm{D}\right)+\mathrm{O}_{3}\right)$ loss rates (in molecules $\mathrm{cm}^{-3} \mathrm{~s}^{-1}$ ) were calculated within the model using the rate-limiting steps of the corresponding reaction cycles. Results were recorded and accumulated into daily means within each model grid cell.

[11] A simple climate model, MAGICC6 (Model for the Assessment of Greenhouse-gas Induced Climate Change version 6) [Meinshausen et al., 2011], was used to convert the emissions scenarios to the surface concentration scenarios required as input to the CCM simulations. Prescribing concentrations rather than emissions boundary conditions breaks the feedback of ozone changes on changes in tropospheric lifetimes. However for our study, omitting this feedback does not affect our conclusions. MAGICC6 can be calibrated to emulate any of the 19 CMIP3 (Coupled Model Intercomparison Project phase 3) Atmosphere-ocean General
Circulation Model (AOGCMs) and the $10 \mathrm{C}^{4} \mathrm{MIP}$ (Coupled Carbon Cycle Climate Model Intercomparison Project) carbon cycle models. For our calculations, MAGICC6 was calibrated to the ECHAM5/MPIOM AOGCM core model parameters, and LLNL model carbon cycle parameters.

\section{Emissions Scenarios}

[12] For the $\mathrm{B} 1$ simulation, surface concentrations of $\mathrm{CO}_{2}$, $\mathrm{N}_{2} \mathrm{O}$ and $\mathrm{CH}_{4}$, commensurate with the SRES B1 emissions scenario, were calculated using MAGICC6 tuned as described above. SSTs and sea-ice concentrations (SICs) were prescribed using output from the UKMO-HadCM3 AOGCM, based on the SRES B1 emissions scenario [Nakicenovic and Swart, 2000]. The SST and SIC datasets were obtained from the World Climate Research Programme's CMIP3 multimodel dataset.

[13] Since the biofuels simulation was constructed to follow the same radiative forcing pathway as the B1 simulation (see below), it used the same SSTs, SICs and $\mathrm{CH}_{4}$ surface concentrations as the B1 simulation. The biofuels simulation was based on findings from Melillo et al. [2009], which suggest that biofuels production and the associated use of nitrogen-based fertilizers could account for $\sim 60 \%$ of total annual $\mathrm{N}_{2} \mathrm{O}$ emissions by 2100 . To capture this impact, an emissions scenario for $\mathrm{N}_{2} \mathrm{O}$, with emissions of 14.3 $\mathrm{MtN}_{2} \mathrm{O}-\mathrm{N}$ in 2100 compared with $5.7 \mathrm{MtN}_{2} \mathrm{O}-\mathrm{N}$ in the B1 scenario, was constructed. MAGICC6 calculated the corresponding surface $\mathrm{N}_{2} \mathrm{O}$ concentrations, which were $443 \mathrm{ppb}$ in 2100 compared with $368 \mathrm{ppb}$ in the B1 scenario (Figure 1a).

[14] $\mathrm{CO}_{2}$ emissions in the biofuels scenario were decreased relative to those prescribed in the B1 scenario such that the global-mean radiative forcing in the biofuels simulation was the same as in the B1 simulation. By keeping the radiative forcing the same in both simulations, we can ensure that any differences seen are attributable to changes in chemistry and are not potentially compromised by changes in dynamics. The reduction in $\mathrm{CO}_{2}$ concentrations also served to simulate the expected reduction in $\mathrm{CO}_{2}$ emissions resulting from biofuels use rather than fossil fuels use. This resulted in $\mathrm{CO}_{2}$ emissions of $3.7 \mathrm{GtC}$ in 2100 in the biofuels scenario, compared with $5.2 \mathrm{GtC}$ in the $\mathrm{B} 1$ scenario (summarized in Table 1, along with $\mathrm{N}_{2} \mathrm{O}$ emissions). The equivalent $\mathrm{CO}_{2}$ surface concentrations in 2100 , calculated using MAGICC, were $532 \mathrm{ppm}$ in the biofuels scenario, compared with $551 \mathrm{ppm}$ in the B1 scenario (Figure 1b).

[15] The A1B simulation used GHG concentrations, SSTs and SICs consistent with the SRES A1B scenario. SSTs and SICs were taken from ECHAM5/MPIOM AOGCM output. SSTs for the A1B and B1 simulations are shown in Figure 1d. $\mathrm{CH}_{4}$ concentrations for the three scenarios are displayed in Figure 1c.

\section{Results and Discussion}

[16] The projected changes in global-mean total column ozone over the 21 st century for the three simulations are summarized in Table 1. In our A1B simulation, global-mean total column ozone is projected to increase by $9.1 \mathrm{DU}$ through the 21 st century, due to a slowing of the halogen ozone-loss cycles (as concentrations of stratospheric 

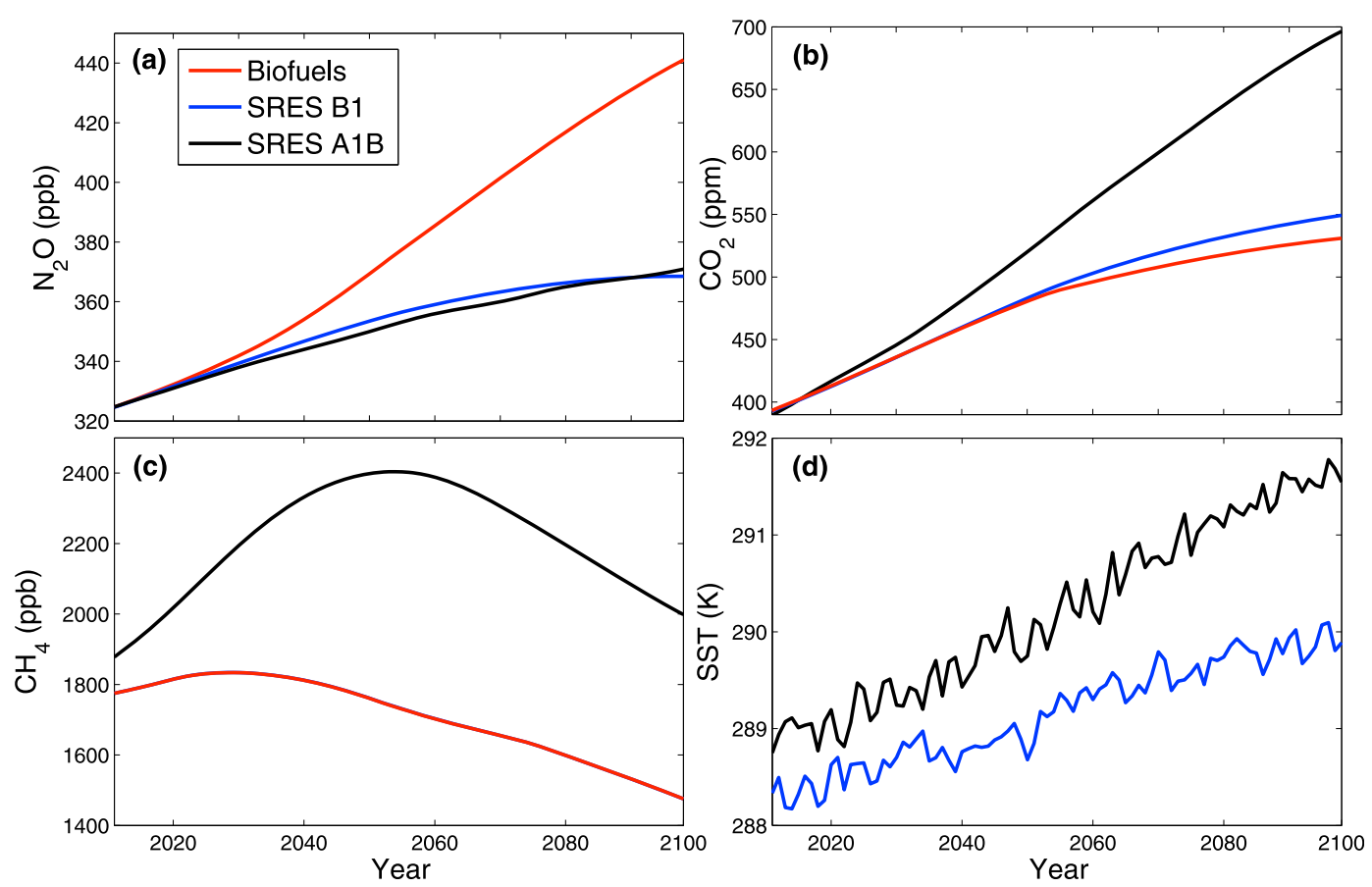

Figure 1. (a) $\mathrm{N}_{2} \mathrm{O}$, (b) $\mathrm{CO}_{2}$, (c) $\mathrm{CH}_{4}$ surface concentrations for the $\mathrm{A} 1 \mathrm{~B}, \mathrm{~B} 1$ and biofuels emissions scenarios. $\mathrm{CH}_{4}$ concentrations are identical for the B1 and biofuels scenario such that the red and blue traces overlay each other. (d) Global-mean SSTs for the A1B and B1 simulations (the biofuels simulation used B1 SSTs).

chlorine and bromine decline) and GHG-induced stratospheric cooling (which slows the temperature-dependent ozone loss cycles [Rosenfield et al., 2002]). This result is consistent with other CCM projections in the SPARC (Stratospheric Processes and their Role in Climate) CCM Validation (CCMVal-2) assessment [SPARC CCMVal, 2010], which also used the SRES A1B scenario.

[17] In the B1 simulation, column ozone decreases by 0.7 DU over the 21 st century since stratospheric cooling (which induces ozone increases) is relatively less than in the A1B simulation where larger stratospheric cooling leads to a 9.1 DU increase in ozone. A larger decrease in column ozone of 2.6 DU is calculated in the biofuels simulation, because greater $\mathrm{N}_{2} \mathrm{O}$ emissions lead to enhanced rates of the ozone-depleting $\mathrm{NO}_{\mathrm{x}}$ cycles.

[18] Ozone differences between the B1 and A1B simulations at the end of the 21 st century are displayed in Figure $2 \mathrm{a}$ as a percentage of ozone in the A1B simulation, and in Figure $2 \mathrm{~b}$ as the difference in total column ozone (B1 minus A1B). This facilitates an assessment of the effect of GHG forcing (for example, driving changes in stratospheric temperature and the BDC) on ozone. The ozone concentrations in the B1 simulation in the upper and lower Antarctic stratosphere and the tropical lower stratosphere are greater than those in the A1B simulation, consistent with the findings of Eyring et al. [2010]. Elsewhere, the B1 simulation ozone concentrations are lower by as much as $20 \%$.

[19] The lower ozone concentrations in the B1 simulation are likely due to: 1) the weaker stratospheric cooling, with the result that the temperature-dependent gas-phase ozone loss cycles slow less than in the A1B simulation; 2) lower $\mathrm{CH}_{4}$ concentrations than in the A1B scenario [Portmann and Solomon, 2007; Fleming et al., 2011] and; 3) reduced strengthening of the BDC, as a result of cooler SSTs
[Fomichev et al., 2007; Bekki et al., 2011], which means that the ozone flux into the southern mid-latitude lower stratosphere is weaker than in the A1B simulation.

[20] Increased tropical lower stratospheric ozone in the B1 simulation is consistent with a difference in the BDC between the $\mathrm{B} 1$ and $\mathrm{A} 1 \mathrm{~B}$ simulations. The slower ascent rate in the tropical lower stratosphere in the B1 simulation allows more time for ozone to form in the rising air parcels than in more quickly ascending air in the $\mathrm{A} 1 \mathrm{~B}$ simulation [Avallone and Prather, 1996]. Elevated lower-stratospheric Antarctic ozone in the B1 simulation is caused by a relatively warmer lower stratosphere; over the 21 st century, Antarctic winter temperatures at $50 \mathrm{hPa}$ average $197 \mathrm{~K}$ in the $\mathrm{B} 1$ simulation compared to $189 \mathrm{~K}$ in the A1B simulation. As a result, polar stratospheric cloud formation, and the associated heterogeneous chlorine and bromine ozone-depleting chemistry, is suppressed in the B1 simulation compared to the A1B simulation. In the $2090 \mathrm{~s}$, there is $\sim 5 \%$ more upper-stratospheric Antarctic ozone in the $\mathrm{B} 1$ simulation than in the A1B simulation because there is less $\mathrm{CH}_{4}$, and hence the ozonedepleting $\mathrm{HO}_{\mathrm{x}}$ cycles (which are dominant in the upper stratosphere) are slower.

[21] Figure 2c displays the same quantity as Figure 2a, but calculated for the difference between the biofuels and B1 simulations. This facilitates an assessment of the effects of larger $\mathrm{N}_{2} \mathrm{O}$ emissions on ozone. Figure $2 \mathrm{c}$ shows that under the biofuels scenario, ozone concentrations are (relatively) suppressed throughout the middle stratosphere and enhanced in the lower stratosphere. However, because the middle stratosphere dominates the ozone column, total column amounts are smaller in the biofuels simulation and up to 11 DU smaller at northern high latitudes (Figure 2d).

[22] In the biofuels simulation, ozone is greater by up to $4 \%$ in the troposphere compared to that in the B1 simulation. 

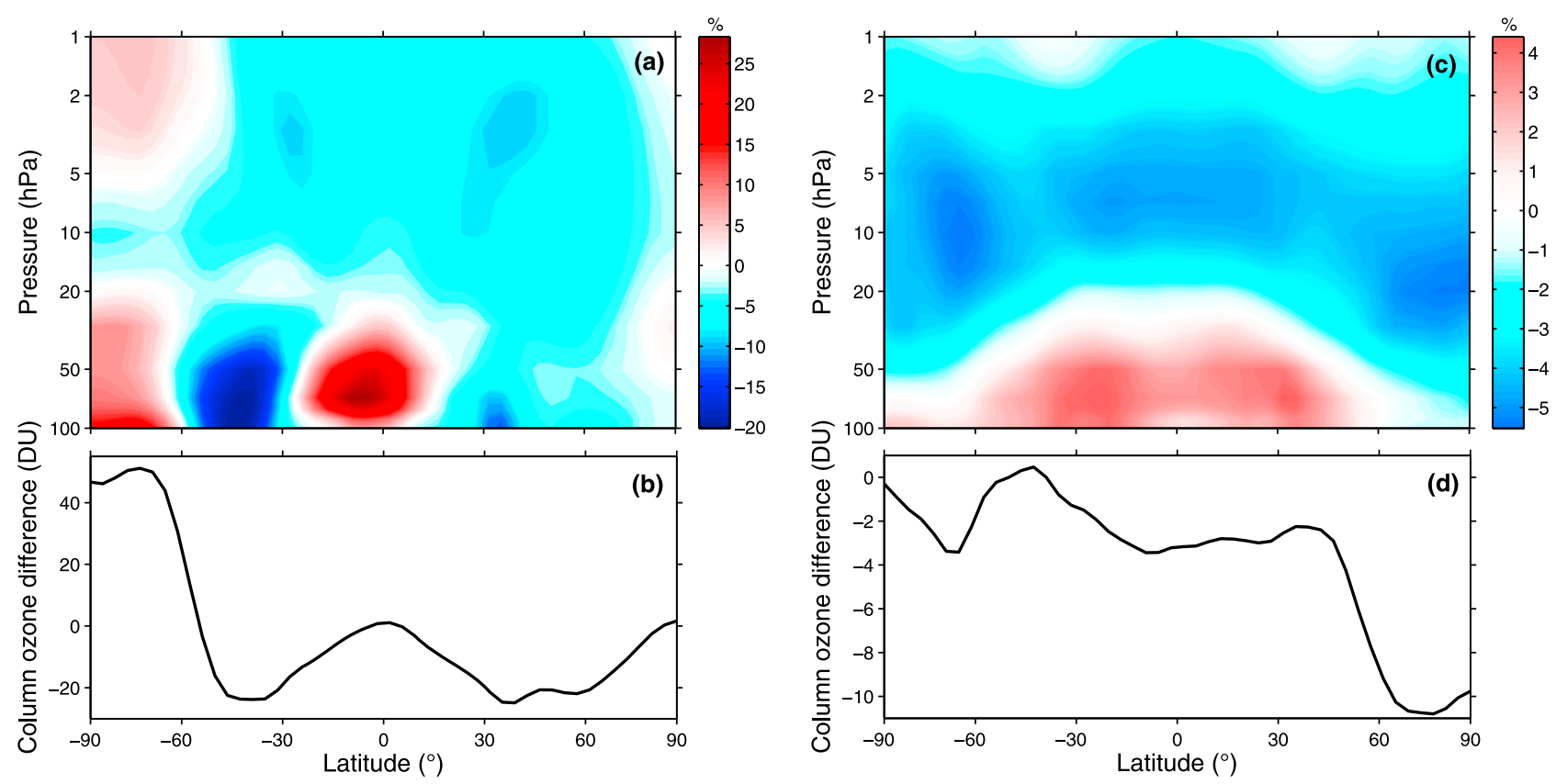

Figure 2. (a) B1 ozone minus A1B ozone in the 2090s decade, calculated as a percentage of ozone in the A1B simulation. (b) 2090s decade B1 total column ozone minus A1B total column ozone. (c) Biofuels ozone minus B1 ozone in the 2090s decade, calculated as a percentage of ozone in the B1 simulation. (d) 2090s decade biofuels total column ozone minus B1 total column ozone.

$\mathrm{N}_{2} \mathrm{O}$ leads to an increase in tropospheric ozone production, via the following reactions involving $\mathrm{NO}_{\mathrm{x}}$ :

$$
\begin{gathered}
\mathrm{OH}+\mathrm{CO}+\mathrm{O}_{2} \rightarrow \mathrm{HO}_{2}+\mathrm{CO}_{2} \\
\mathrm{HO}_{2}+\mathrm{NO} \rightarrow \mathrm{NO}_{2}+\mathrm{OH} \\
\mathrm{NO}_{2}+\mathrm{h} \nu \rightarrow \mathrm{NO}+\mathrm{O} \\
\mathrm{O}+\mathrm{O}_{2}+\mathrm{M} \rightarrow \mathrm{O}_{3}+\mathrm{M}
\end{gathered}
$$

Ozone production by this mechanism is generally insignificant in the stratosphere, where the concentration of $\mathrm{CO}$ is too small [Lanzendorf et al., 2001].

[23] In the middle and upper stratosphere, ozone in the biofuels scenario is up to $5 \%$ less than that in the B1 simulation, since $\mathrm{N}_{2} \mathrm{O}$ concentrations are higher, leading to a faster rate of the ozone-depleting $\mathrm{NO}_{\mathrm{x}}$ cycles. These cycles

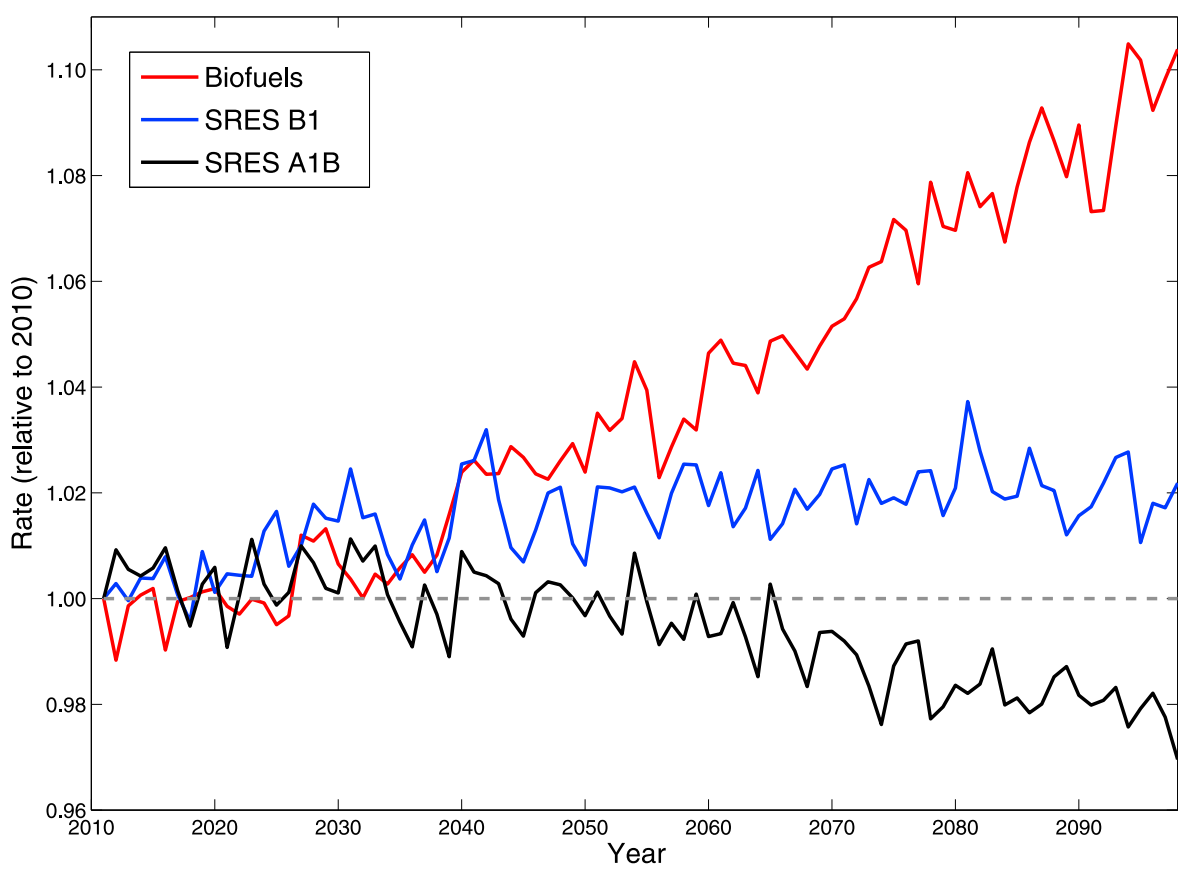

Figure 3. Global-mean rate of the $\mathrm{NO}_{\mathrm{x}}$ ozone loss cycles, averaged over 1-100 hPa and normalized to 1.0 in 2010 . The differences between the biofuels and $\mathrm{B} 1$ simulations are largely a consequence of different $\mathrm{N}_{2} \mathrm{O}$ emissions, while those between the $\mathrm{B} 1$ and $\mathrm{A} 1 \mathrm{~B}$ simulations are largely due to temperature differences. 
do not occur in the troposphere where $\mathrm{O}$ and $\mathrm{O}_{3}$ concentrations are minimal.

[24] Figure 3 shows the combined rate of the two $\mathrm{NO}_{\mathrm{x}}$ ozone-loss cycles (Cycles I and II), averaged over $1-100 \mathrm{hPa}$, relative to their rate in 2010 for each of the three simulations. Despite increasing $\mathrm{N}_{2} \mathrm{O}$ emissions in the A1B simulation, $\mathrm{NO}_{\mathrm{x}}$-induced ozone depletion slows over the 21 st century (as described by L. E. Revell et al., The effectiveness of $\mathrm{N}_{2} \mathrm{O}$ in depleting stratospheric ozone, submitted to Geophysical Research Letters, 2011). The $\mathrm{B} 1$ simulation has $\mathrm{N}_{2} \mathrm{O}$ emissions almost identical to those in the A1B simulation, yet because the stratosphere cools relatively less, the rate at which the $\mathrm{NO}_{\mathrm{x}}$ cycles deplete ozone increases by $\sim 2 \%$ between 2010 and 2100. Finally, in the biofuels simulation, the rate of ozone-depleting $\mathrm{NO}_{\mathrm{x}}$ chemistry increases by $\sim 10 \%$ over the 21 st century owing to the large increase in $\mathrm{N}_{2} \mathrm{O}$ concentrations.

\section{Conclusions}

[25] We have presented the effects of three different GHG emissions scenarios on stratospheric ozone. The SRES A1B scenario is the scenario on which the majority of the SPARC CCMVal-2 simulations were based. In our A1B simulation, global-mean total column ozone increased by 9.1 DU over the 21 st century due to decreasing halogen concentrations and GHG-induced stratospheric cooling. Such an increase was not observed in the simulation based on the SRES B1 scenario (0.7 DU decrease), which has lower $\mathrm{CO}_{2}$ and $\mathrm{CH}_{4}$ emissions. Increasing $\mathrm{N}_{2} \mathrm{O}$ emissions increase the rate of $\mathrm{NO}_{\mathrm{x}}$-catalyzed ozone loss, and this effect becomes more pronounced when the stratosphere cools relatively less, as it does in the biofuels simulation (2.6 DU decrease). Therefore, the reduction in $\mathrm{CO}_{2}$ emissions achieved by switching to biofuels is not large enough to compensate for the deleterious effects of associated increases in $\mathrm{N}_{2} \mathrm{O}$ emissions on stratospheric ozone. Increased biofuels production and consumption could therefore be damaging to the ozone layer.

[26] Acknowledgments. We would like to thank Malte Meinshausen for providing us with the MAGICC6 model. We acknowledge the modeling groups for making their model output available for analysis, the Program for Climate Model Diagnosis and Intercomparison (PCMDI) for collecting and archiving these data, and the WCRP's Working Group on Coupled Modeling (WGCM) for organizing the model data analysis activity. The WCRP CMIP3 multi-model dataset is supported by the Office of Science, U.S. Department of Energy.

[27] The Editor thanks two anonymous reviewers for assisting with the evaluation of this paper.

\section{References}

Avallone, L. M., and M. J. Prather (1996), Photochemical evolution of ozone in the lower tropical stratosphere, J. Geophys. Res., 101(D1), 1457-1461, doi:10.1029/95JD03010.

Bekki, S., et al. (2011), Future ozone and its impact on surface UV, in Scientific Assessment of Ozone Depletion: 2010, Global Ozone Res. Monit. Proj. Rep. 52, chap. 3, pp. 1-60, World Meteorol. Organ., Geneva, Switzerland.

Bessou, C., F. Ferchaud, B. Gabrielle, and B. Mary (2011), Biofuels, greenhouse gases and climate change. A review, Agron. Sustainable Dev., 31 , 1-79, doi:10.1051/agro/2009039.

Cook, P. A., and H. K. Roscoe (2009), Variability and trends in stratospheric $\mathrm{NO}_{2}$ in Antarctic summer, and implications for stratospheric $\mathrm{NO}_{\mathrm{y}}$, Atmos. Chem. Phys., 9, 3601-3612, doi:10.5194/acp-9-3601-2009.

Crutzen, P. J. (1970), The influence of nitrogen oxides on the atmospheric ozone content, Q. J. R. Meteorol. Soc., 96, 320-325, doi:10.1002/ qj. 49709640815 .
Crutzen, P. J., A. R. Mosier, K. A. Smith, and W. Winiwarter (2008), $\mathrm{N}_{2} \mathrm{O}$ release from agro-biofuel production negates global warming reduction by replacing fossil fuels, Atmos. Chem. Phys., 8, 389-395, doi:10.5194/ acp-8-389-2008.

Daniel, J. S., et al. (2007), Halocarbon scenarios, ozone depletion potentials, and global warming potentials, in Scientific Assessment of Ozone Depletion: 2006, Global Ozone Res. Monit. Proj. Rep. 50, chap. 8 , pp. 1-39, World Meteorol. Organ., Geneva, Switzerland.

Eyring, V., et al. (2010), Sensitivity of 21 st century stratospheric ozone to greenhouse gas scenarios, Geophys. Res. Lett., 37, L16807, doi:10.1029/2010GL044443.

Fleming, E. L., C. H. Jackman, R. S. Stolarski, and A. R. Douglass (2011), A model study of the impact of source gas changes on the stratosphere for 1850-2100, Atmos. Chem. Phys., 11, 8515-8541, doi:10.5194/acp-118515-2011.

Fomichev, V. I., A. I. Jonsson, J. de Grandpré, S. R. Beagley, C. McLandress, K. Semeniuk, and T. G. Shepherd (2007), Response of the middle atmosphere to $\mathrm{CO}_{2}$ doubling: Results from the Canadian Middle Atmosphere Model, J. Clim., 20, 1121-1144, doi:10.1175/ JCLI4030.1.

Forster, P., et al. (2007), Changes in atmospheric constituents and in radiative forcing, in Climate Change 2007: The Physical Science Basis. Contribution of Working Group I to the Fourth Assessment Report of the Intergovernmental Panel on Climate Change, edited by S. Solomon et al., pp. 129-234, Cambridge Univ. Press, Cambridge, U. K.

Jonsson, A. I., J. de Grandpré, V. I. Fomichev, J. C. McConnell, and S. R. Beagley (2004), Doubled $\mathrm{CO}_{2}$-induced cooling in the middle atmosphere: Photochemical analysis of the ozone radiative feedback, J. Geophys. Res., 109, D24103, doi:10.1029/2004JD005093.

Lanzendorf, E. J., T. F. Hanisco, P. O. Wennberg, R. C. Cohen, R. M. Stimpfle, J. G. Anderson, R. S. Gao, J. J. Margitan, and T. P. Bui (2001), Establishing the dependence of $\left[\mathrm{HO}_{2}\right] /[\mathrm{OH}]$ on temperature, halogen loading, $\mathrm{O}_{3}$, and $\mathrm{NO}_{\mathrm{x}}$ based on in situ measurements from the NASA-ER2, J. Phys. Chem. A, 105, 1535-1542, doi:10.1021/ jp0023841.

Lee, A. M., R. L. Jones, I. Kilbane-Dawe, and J. A. Pyle (2002), Diagnosing ozone loss in the extratropical lower stratosphere, J. Geophys. Res., 107(D11), 4110, doi:10.1029/2001JD000538.

Meinshausen, M., S. C. B. Raper, and T. M. L. Wigley (2011), Emulating coupled atmosphere-ocean and carbon cycle models with a simpler model, MAGICC6 - Part 1: Model description and calibration, Atmos. Chem. Phys., 11, 1417-1456, doi:10.5194/acp-11-1417-2011.

Melillo, J. M., J. M. Reilly, D. W. Kicklighter, A. C. Gurgel, T. W. Cronin, S. Paltsev, B. S. Felzer, X. Wang, A. P. Sokolov, and C. A. Schlosser (2009), Indirect emissions from biofuels: How important?, Science, 326, 1397-1399, doi:10.1126/science.1180251.

Nakicenovic, N., and R. Swart (Eds.) (2000), IPCC Special Report on Emissions Scenarios, Cambridge Univ. Press, Cambridge, U. K.

Portmann, R. W., and S. Solomon (2007), Indirect radiative forcing of the ozone layer during the 21 st century, Geophys. Res. Lett., 34, L02813, doi:10.1029/2006GL028252.

Ravishankara, A. R., J. S. Daniel, and R. W. Portmann (2009), Nitrous Oxide $\left(\mathrm{N}_{2} \mathrm{O}\right)$ : The dominant ozone-depleting substance emitted in the 21 st century, Science, 326, 123-125, doi:10.1126/science. 1176985 .

Rosenfield, J. E., and A. R. Douglass (1998), Doubled $\mathrm{CO}_{2}$ effects on $\mathrm{NO}_{\mathrm{y}}$ in a coupled 2D model, Geophys. Res. Lett., 25, 4381-4384, doi:10.1029/1998GL900147.

Rosenfield, J. E., A. R. Douglass, and D. B. Considine (2002), The impact of increasing carbon dioxide on ozone recovery, J. Geophys. Res., 107, 4049, doi:10.1029/2001JD000824.

Sander, S. P., et al. (2006), Chemical kinetics and photochemical data for use in atmospheric studies, JPL Publ., 06-2, 523 pp.

Sander, S. P., et al. (2009), Chemical kinetics and photochemical data for use in atmospheric studies: Update to key reactions, JPL Publ., 09-31.

Schraner, M., et al. (2008), Chemistry-climate model SOCOL: Version 2.0 with improved transport and chemistry/microphysics schemes, Atmos. Chem. Phys., 8, 5957-5974, doi:10.5194/acp-8-5957-2008.

Smeets, E. M. W., L. F. Bouwmanw, E. Stehfest, D. P. van Vuuren, and A. Posthuma (2009), Contribution of $\mathrm{N}_{2} \mathrm{O}$ to the greenhouse gas balance of first-generation biofuels, Global Change Biol., 15, 1-23, doi:10.1111/ j.1365-2486.2008.01704.x.

SPARC CCMVal (2010), SPARC report on the evaluation of chemistryclimate models, SPARC Rep. 5, WCRP-132, WMO/TD 1526, edited by V. Eyring, T. G. Shepherd, and D. W. Waugh, World Clim. Res. Programme, Geneva, Switzerland. 